\title{
Niilismo Jurídico e Ideologias Políticas Radicais: Uma Observação sobre a História do Constitucionalismo Russo a partir d' Os Demônios, de Fiódor Dostoiévski
}

\author{
Luis Rosenfield \\ Doutorando em Filosofia (PUCRS) e em Direito (UNISINOS). E-mail: \\ luis.rosenfield@gmail.com
}

Resumo: O presente artigo utiliza o romance Os demônios, de Fiódor Dostoiévski para abordar questões centrais da filosofia política e da teoria constitucional. Nesse estudo, a literatura funciona como eixo de reflexão que torna possível enxergar um retrato consistente das encruzilhadas ideológicas do final do século XIX, e suas repercussões no plano da história das ideias. Em síntese, dentro da tradição dos estudos em direito e literatura e através de metodologia ensaística, busca-se colocar a história do constitucionalismo russo em contraste com a ascensão das ideologias políticas radicais. A investigação está organizada ( $i$ ) na breve apresentação da vida e da obra de Fiódor Dostoiévski; (ii) e no aprofundamento do enredo d'Os demônios, focando-se nos eventos de violência revolucionária e no conteúdo político do romance; (iii) com o objetivo, então, de construir uma análise do constitucionalismo russo diante da radicalização política, especialmente em sua formatação niilista; (iv) para, por fim, esboçar o conceito de "niilismo jurídico" através dessa análise sobre a história do direito russo.

Palavras-chave: Fiódor Dostoiésvki. Niilismo. Direito e Literatura. Os demônios. Constitucionalismo.

\section{UNIVERSIDADE FEDERAL DA PARAÍBA}




\title{
Niilismo Jurídico e Ideologias Políticas Radicais: Uma Observação sobre a História do Constitucionalismo Russo a partir d' Os Demônios, de Fiódor Dostoiévski ${ }^{1}$
}

\author{
Luis Rosenfield
}

\section{INTRODUÇÃO}

O presente artigo se insere na tradição dos estudos em Direito e Literatura, lançando mão da obra seminal de Fiódor Dostoiésvki, Os demônios, como fio condutor de uma análise que perpassa reflexões sobre direito constitucional, história do direito e filosofia política. Essa abordagem interdisciplinar está situada no limiar entre Direito, História e Política, utilizando-se da Literatura como instrumento de trânsito entre essas disciplinas no plano da história das ideias. Como se sabe, a história do direito é marcada pela relação turbulenta entre direito e política: a própria ideia de "constitucionalismo" implica, em certa medida, refletir sobre os perenes atritos entre essas duas esferas (VILE, 1998, p. 345-384).

Historicamente, cada país possui um modo peculiar de arquitetar seu sistema político e constitucional, que estabelecerá freios e contrapesos adequados à sua realidade, às suas necessidades empíricas. Trabalhar os conceitos de Estado de Direito e de Estado Constitucional implica analisar os descompassos do direito e as turbulências sociais da evolução política de um determinado lugar.

${ }^{1} \mathrm{O}$ presente trabalho foi realizado com apoio da Coordenação de Aperfeiçoamento de Pessoal de Nível Superior - Brasil (CAPES) - Código de Financiamento oo1. 
Um bom exemplo dessa intrincada relação é o caso da Rússia descrita por Fiódor Dostoiévski em Os demônios. Como se verá a seguir, a narrativa do mestre russo revela que aquele momento único na história foi a gênese de determinada forma revolucionária que, décadas mais tarde, ganhou corpo e intensidade no século XX.

A realidade daquele período da história russa, narrado com detalhes por Dostoiévski, é composta por uma mistura entre agitação social, terrorismo revolucionário e violência política. Naquele momento histórico se observava o crescimento das ideologias políticas radicais que redimensionaram o constitucionalismo ocidental como um todo, pois os eventos trabalhados na ficção de Dostoiévski podem ser observados como a antessala da Revolução Russa de 1917. A narrativa d'Os demônios está situada em meados do século XIX, em um período marcado pela gradual decadência da autocracia czarista. Nesse contexto de transformação política, a atuação das frágeis instituições do incipiente constitucionalismo liberal russo abriu caminho para um relativismo moral que foi explorado pelo que se convencionou chamar de niilismo.

O direito russo daquela época se distinguia dos sistemas jurídicos do resto da Europa por não ter desenvolvido códigos - e muito menos uma constituição -, o que acarretava atrasos evidentes devido ao caráter obscuro e arcaico da legislação (WORTMAN, 1976, p. 2-33). A partir desse vácuo normativo, as ascendentes filosofias niilistas se baseavam na negação da religião e de outros sistemas morais como fontes orientadores legítimas da vida social. Dessa forma, um dos objetivos da presente análise é investigar as implicações do florescimento desse niilismo endossado por certos revolucionários russos (niilismo esse que não era somente filosófico, mas também empiricamente situado). Para além da relevante discussão entre filosofia política e direito constitucional através da literatura, o objetivo do presente artigo é esboçar um conceito de nülismo jurídico, baseado inicialmente no desenvolvimento constitucional da Rússia, que possa ser replicado a outras experiências constitucionais comparadas. 
A queda da monarquia czarista russa em 1917 significou a ascensão do bolchevismo soviético e a consequente consolidação da União Soviética: essa transição abrupta no constitucionalismo russo representou um dos principais acontecimentos dos últimos duzentos anos. Esse processo começa, de certa forma, com a radicalização política no país de meados do século XIX, que foi detalhadamente retratado no principal romance político de Dostoiévski, no qual se descreve de modo precioso o fenômeno da gênese do terrorismo revolucionário russo.

Essa sorte de construção entre Direito e Literatura busca sair do lugar comum das análises jurídicas, apresentando o constitucionalismo através da história das ideias jurídicas e da reflexão filosófico-política. Os demônios, por seu conteúdo profético, antecipou as encruzilhadas que a Rússia enfrentaria com o declínio do Império e das estruturas políticas czaristas. O ocaso das estruturas políticas russas reflete os dilemas que dezenas de países também atravessariam nos últimos dois séculos com a radicalização dos discursos políticos e com a ascensão dos mais variados métodos de terror durante todo século XX.

Com isso, a literatura funciona como eixo de reflexão que torna possível enxergar um retrato consistente das encruzilhadas ideológicas da segunda metade do século XIX, ao mesmo tempo que constrói um enredo ficcional plausível dos sentimentos e motivos, ações e sofrimentos que sustentavam essas convicções e ideologias. Esse estudo possui caráter ensaístico, pois procura refletir sobre determinados fenômenos, não havendo propriamente uma pergunta guia que sirva de norte para a análise. Dessa forma, a investida desse estudo está organizada (i) na breve apresentação da vida e da obra de Fiódor Dostoiévski; (ii) e no aprofundamento do enredo d'Os demônios, focando-se nos eventos de violência revolucionária e no conteúdo político do romance; (iii) para, então, construir uma análise do constitucionalismo russo diante da radicalização política; (iv) e, por fim, esboçar a construção de um conceito de "niilismo jurídico" a partir das reflexões sobre a história do direito russo. 


\section{FIÓDOR DOSTOIÉVSKI: O AUTOR, SUA OBRA E OS DEMÔNIOS}

Fiódor Mikhailovitch Dostoiévski (1821-1881) se notabilizou por uma extensa obra literária e jornalística, sendo comumente citado como um dos maiores escritores de todos os tempos. Sua literatura está ambientada na turbulenta vida social e política da Rússia do século XIX, e nesse ambiente são frequentemente abordadas questões psicológicas, explorando-se a complexidade da psique humana. Os temas religiosos, jurídicos e filosóficos permeiam parte considerável de seus romances e, por essa razão, no plano da leitura transversal entre Direito e Literatura, dois livros de Dostoiévski se consolidaram como textos de referência para a análise jusliterária: Crime e castigo e Os irmãos Karamázov são tradicionalmente utilizados para a reflexão jurídica em virtude da representação dos ritos das instituições judiciárias (OLIVO, 2012; ZAGREBELSKY, 2015).

Durante o reinado do Czar Nicolau I, Dostoiévski se envolveu em uma organização literária que se opunha à autocracia russa e à servidão, o chamado Círculo Petrashevski, e foi julgado pela Justiça czarista por participar do grupo considerado clandestino pois discutia textos filosóficos e literários banidos pelo governo. Em 1849, Dostoiévski foi processado e condenado junto com outros membros da organização à pena de morte por pelotão de fuzilamento. Os membros do Círculo Petrashevski foram, de fato, levados diante de um pelotão de fuzilamento, mas houve apenas a simulação da execução. Após essa experiência traumática, Dostoiévski ainda foi levado a cumprir uma pena de quatro anos de trabalhos forçados na 
Sibéria, que se somaram a mais seis anos de serviço militar compulsório nos limites territoriais do Império Russo no seu flanco oriental.

Mesmo com duríssima pena imposta pelo czar em razão de suas atividades de intelectual progressista, Dostoiévski se manteve um fervoroso seguidor das tradições russas e da Igreja Ortodoxa Russa. No plano político, defendia posicionamentos tidos como eslavófilos (que defendiam que a Rússia deveria se manter firme na defesa de suas tradições ancestrais), em detrimento da importação de ideias ocidentalistas (segundo as quais a Rússia deveria se modernizar nos moldes dos principais países da Europa ocidental).

Um dos autores que melhor avançou na questão do nïlismo em Dostoiévski foi Albert Camus quando, no ano de 1959, adaptou Os demônios para o teatro e também dirigiu a peça (com mais de quatro horas de duração) (CAMUS, 1959). As lições contidas na obra-prima de Dostoiévski influenciaram as convicções do escritor francoargelino contra a introdução do niilismo na filosofia ocidental. De certo modo, é possível afirmar que o próprio conceito de absurdo habilidosamente construído por Camus está calcado na negação da filosofia niilista e no combate às radicalizações políticas de sua época. Esse fenômeno resta suficientemente claro na conhecida obra de Camus, $O$ mito de Sísifo, na qual se nota que as angústias contidas n'Os demônios de Dostoiévski orientaram o debate em torno do conceito de absurdo (CAMUS, 2010, p. 142-152).

Em trabalho recente, o filósofo Charles Taylor utiliza Os demônios como símbolo do desaparecimento abrupto da religião na modernidade como ícone norteador da moral, pontuando a importância da leitura do escritor russo para compreender o processo de secularização no século XIX. A crítica ao uso da violência e a recusa em empreender a reforma social radical, presente n'Os demônios, serve para Taylor como eixo filosófico para abordar o relativismo moral, o conceito de bem e mal e o papel da crença no pensamento ocidental (TAYLOR, 2010, p. 817, 852 e 857). Claudio Magris, por sua vez, qualifica as ações violentas contidas n'Os 
Niilismo Jurídico e Ideologias Políticas Radicais: Uma Observação...

demônios como um clássico e exemplar modelo de messianismo terrorista, no que Dostoiévski teria antecipado a situação contemporânea de perda de referenciais morais através de sua furiosa e visionária sátira política (MAGRIS, 2001, p. 163-167).

Com isso, a presente pesquisa busca estabelecer algumas balizas para o resgate histórico das profecias contidas n'Os Demônios: a antecipação de Dostoiévski do fator desagregador do terrorismo revolucionário na Rússia do século XIX, uma vez que ele profetizou as convulsões sociais e políticas que ocorreriam na Rússia e na Europa, que depois se alastraram para o resto do mundo. Sua literatura funciona como meio privilegiado para descortinar a história institucional do direito e a própria filosofia política, como se verá adiante.

O biógrafo de Dostoiévski, Josef Frank, descreve que a intrincada narrativa de Os demônios foi escrita no limiar entre o poema e o panfleto (FRANK, 2008b, p. 539), e difere substancialmente de outros romances do autor. Nesse romance político, são trabalhadas questões políticas em detalhe, fornecendo-se um rico retrato do choque geracional no pensamento progressista russo. Se, por um lado, a obra proporciona continuidade à tradição de Dostoiévski em despejar forte conteúdo psicológico em sua construção literária; por outro, a marca distintiva d'Os demônios em relação a outros romances é precisamente a pesada conotação política da trama, com sua feroz crítica às ideologias radicais que tomavam corpo na Rússia de meados do século XIX.

O período que compreende os anos de 1865 a 1871 foi chamado por Frank de "anos milagrosos", pois precisamente nesse corte temporal foram escritos Crime e castigo e Os demônios, que representam o ponto culminante da carreira literária do gênio russo. Essa etapa da vida de escritor, ao mesmo tempo, revela as inquietações filosóficas, sociais e político-jurídicas que marcarão a realidade russa nos anos seguintes (FRANK, 2008b, p. 539-567). O artigo busca destacar determinados encontros e convergências entre a literatura de Dostoiévski, a história do direito russo, a filosofia 
política niilista e a gênese do terrorismo revolucionário. Isso porque, para se compreender os atuais desafios do constitucionalismo contemporâneo, necessita-se da avaliação de um contexto tão importante para os desdobramentos históricos posteriores, pois são precisamente nas fissuras da história constitucional que se deve buscar substrato para fazer avançar a história das ideias políticas e jurídicas.

\section{AS PROFECIAS D'OS DEMÔNIOS: TERRORISMO, VIOLÊNCIA E REVOLUÇÃO}

Dostoiévski motivou-se a escrever Os demônios por um episódio verídico da história russa: o assassinato, em 1869, do estudante I. Ivánov, membro de uma célula revolucionária de orientação niilista, por um de seus companheiros, o líder da organização, Serguei G. Netcháiev (FRANK, 2008b, p. 569-613). Josef Frank aponta com precisão que parte considerável do conteúdo d'Os demônios se baseia nas atas e documentos do processo judicial do Caso Netchaiév, visto que as autoridades czaristas disponibilizaram para os jornais e as revistas da época, excepcionalmente, vários detalhes acerca do processamento do célebre assassinato, contrariando a tradição czarista de processar e julgar as atividades subversivas de forma sigilosa e secreta (FRANK, 2008b, p. 569-573).

A narrativa d'Os demônios foi articulada de forma dramática e complexa, voltada a dotar o romance de um caráter antirrevolucionário, trabalhando inclusive formas de violência explícita ao descrever casos de assassinato, suicídio, linchamento e estupro de menor de idade. Dostoiévski tentou se manter fiel aos relatos das atividades revolucionárias daquele momento histórico, focado em combater o nascente extremismo russo que tanto lhe 
causava ojeriza. Obviamente, na sua ficção o escritor aumentou e amplificou os objetivos originais do grupo de Netchaiév e seus partidários. Por essa razão, Os demônios representa o mito de uma época - e não história política (FRANK, 2008, p. 572) -, pois o romance incorpora duas caraterísticas centrais da literatura russa: a imbricação entre o trágico e o fantástico (STEINER, 2006, p. 156157).

A elaboração literária de Dostoiévski avoca a construção de uma mitologia política, não representando um libelo meramente imaginário e fictício sobre a radicalização política de seu tempo e, tampouco, um retrato fiel e historiográfico de eventos reais (FRANK, 2008, p. 569-573). O thriller político meticulosamente desenhado por Dostoiévski apresenta traços do amadurecimento de seus ideais conservadores e religiosos, voltados à proteção dos valores morais do Cristianismo Ortodoxo Russo e de um crescente nacionalismo eslavófilo. Ainda que Dostoiévski tenha defendido e militado por uma série de pautas vinculadas ao desenvolvimento do liberalismo europeu (liberdade de imprensa, liberdade de reunião, garantias individuais, etc), Os demônios representa uma poderosa demonstração do caráter teológico de sua escrita, permeada por uma atmosfera intensamente religiosa (STEINER, 2006, p. 31).

Para Dostoiévski, o jornalismo representava um repositório constante de dramas pessoais e de problemas da vida quotidiana: o escritor "encontrava nos jornais uma confirmação de sua própria visão tencionada da realidade" (STEINER, 2006, p. 106). No que se refere especificamente a Os demônios, George Steiner afirma que

O aspecto factual da gênese de Os Demônios é ainda mais diverso. Como sabemos, a estrutura do romance representa um compromisso instável entre fragmentos do ciclo projetado em A Vida de um Grande Pecador e a dramatização de um crime político. $O$ atentado de Karakozov à vida do Czar, em abril de 1866, figurava entre os primeiros impulsos de Os Demônios; mas foi o assassinato de um estudante, Ivanov, sob as ordens do líder niilista Nechaiev, em 21 de novembro de 1869, que forneceu a Dostoiévski seu foco narrativo. Associando todos os jornais russos disponíveis em Dresden, 
Dostoiévski seguiu o caso Nechaiev com atenção apaixonada. Mais uma vez, ele experimentava a estranha sensação de ter previsto o crime, de ter antecipado, através da intuição e devido a sua filosofia política, a progressão necessária que vai do niilismo ao assassinato. $\mathrm{Na}$ maior parte dos esboços para Os Demônios, o personagem que ia se tornar Piotr Stepanovich Verkhovenski é designado simplesmente de "Nechaiev" (2006, p. 107).

O romance coloca em evidência a forte contraposição entre a chamada geração de 1840, marcada pelo idealismo liberal, e a geração de 1860, que adota os princípios revolucionários nülistas e a reforma radical da sociedade como alternativa política. Na trama, o intelectual provinciano Stiepan Trofímovitch Vierkhovénski, protagonista da primeira parte do romance, encarna o tradicional pensamento liberal que colocava em cheque a estrutura do despotismo imperial czarista. Enquanto, por outro lado, o jovem Nikolai Stavrogin, líder da célula revolucionária instalada na província, encarna o niilismo radical que começava a assolar a Rússia em meados do século XIX.

$\mathrm{O}$ enredo da obra gira em torno dos eventos corriqueiros de uma pequena cidade provinciana que acaba sendo alvo dessa célula revolucionária, liderada por Nikolai Stavrogin. Orientados pelo relativismo moral, o grupo revolucionário passa a cometer atos de gradual desagregação social e política, visando a desestabilizar o sistema constituído. Tais atos de agitação e sabotagem, habilidosamente arquitetados, culminam nas mais diversas ações violentas, como assassinatos e suicídios. A vida da província acaba sendo virada de cabeça para baixo. Todo tipo de horror passa a tomar conta do quotidiano: personagens cometem suicídio, atentam contra a vida uns dos outros em linchamentos, emboscadas e assassinatos políticos. A rede de intrigas revolucionária ganha consistência e passa a ameaçar a frágil estabilidade política da província.

A obsessão de Dostoiévski pela temática do suicídio foi alimentada pelo famoso jurista liberal do Império Russo, Anatolií Koni, que lhe forneceu dezenas de cartas de suicídio originais que 
Niilismo Jurídico e Ideologias Políticas Radicais: Uma Observação...

havia reunido em casos judiciais com o passar dos anos (DOSTOIÉVSKI, 2010, p. 981-982). Não somente isso, Dostoiévski buscava com Koni conhecimentos técnicos, a partir da larga experiência forense do advogado, sobre as tendências suicidas e os impulsos autodestrutivos (GONZÁLEZ, 2012, p. 91-134)².

A história contida em Os demônios é contada por personagem secundário, chamado Anton Lavrentyevich, amigo e confidente do intelectual provinciano Stiepan Trofímovitch Vierkhovénski. Observa-se que, do modo pelo qual é estruturada, a narrativa possui relevantes peculiaridades, apesar de ser construída claramente em terceira pessoa, por vezes a escritura de Dostoiévski se transforma em narração de terceira pessoa onisciente. Isso significa que o romance acaba por abarcar as mais diversas vozes e lugares de fala que compõem a vida quotidiana: rumores, boatos, escândalos, opiniões, intrigas. O fenômeno da polifonia, tornado célebre por Bakthin, atinge seu ponto culminante na intertextualidade da trama construída por Dostoiéveski (2015, p. 3-51).

O romance é entrecortado pela mistura entre o relato tedioso do quotidiano da vida interiorana e a radicalização política dos revolucionários. O viés jornalístico agrega em complexidade à elaboração literária do quadro de agitação política e social que atingia o Império Russo. Esse contraste proposital transforma o relato literário em um complexo laboratório dos hábitos e costumes da época. Na ficção, o relato das turbulência políticas que tomavam conta da Rússia na segunda metade do século XIX evidenciou um repositório de crenças políticas e usos do direito.

Seria possível afirmar que Os demônios representa um verdadeiro laboratório de engenharia social, antecipando desdobramentos em direito e política, que se seguiriam no final do século XIX até meados do século XX, especialmente com o fim da

${ }^{2} \mathrm{O}$ resgate da intensa interlocução entre Koni e Dostoiéveski (e também entre o jurista com Tolstói e Tchekhov) foi recentemente empreendido por Calvo González, especialmente para o público não versado no idioma russo. 
religião como normatividade orientadora da sociedade e com a gradativa desagregação social causada por esse fenômeno.

Para Nabokov, o thriller de Dostoiévski apresenta os cenários mais sombrios e sinistros, a coloração obscura da paisagem russa é construída com a intenção de associar as atividades revolucionárias aos pântanos, à névoa fumacenta que absorve os raios de luz da manhã, à chuva cinzenta, ao tempo úmido e aos dias melancólicos do rígido clima da estepe russa (NABOKOV, 2014, p. 177).

Através dessa ambientação enegrecida, Dostoiévski conduz o leitor a um mundo insólito e absurdo, marcado pela falta de balizas éticas e morais; pelo esfacelamento da tradição e da fé. Para o escritor, o cenário russo de sua época estava povoado de tons apocalípticos, em que a autoridade da Palavra da cristandade ortodoxa russa era substituída pelo Nada do relativismo moral niilista. Mais uma vez aqui, a experiência religiosa ortodoxa está presente nas figuras do Juízo Final sempre iminente no imaginário dostoievskiano; na tintura de pesadelo que, por vezes, toma conta do enredo (STEINER, 2006, p. 135-140).

Nas linhas que se seguem, pretende-se recontar determinados trechos fragmentados da obra, que servem para melhor introduzir as análises do artigo e destacar seu conteúdo político-jurídico. Dividido em três partes, a trama começa com a descrição da bucólica vida na província, especialmente sob a ótica dos eventos que se desenrolam em Skvoreshniki, a grande propriedade da nobre Varvara Pietrovna Stavrogina. O enredo segue a pacata vida de Stiepan Trofímovitch Vierkhovénski, intelectual respeitado de uma pequena cidade provinciana russa, que vive sob os auspícios emocionais e financeiros de Varvara Pietrovna, e que fora inicialmente empregado para desempenhar o papel de tutor do filho da nobre Varvara, o protagonista do romance, o já citado líder revolucionário Nikolai V. Stavrogin.

A primeira parte do romance inicia com a volta de Varvara Pietrovna de viagem à Suíça, feita por ocasião de visita a seu filho. Desde o começo da história, a mãe já desconfia de que algo estranho 
Niilismo Jurídico e Ideologias Políticas Radicais: Uma Observação...

acontece em torno de Stavrogin, e sua preocupação se centra em alguma "intriga" fruto de suas ações no estrangeiro. A preocupação de Varvara Pietrovna é de ordem matrimonial, visto que espera que Nikolai Stavrogin se case com a nobre Liza, filha de sua amiga Paskrovia.

Em linhas gerais, a vida pacata da província começa a se transformar após a chegada de Maira Lebiadkina na cidade, mulher chamada de "louca" em razão de suas fortes debilidades mentais. Maira Lebiadkina está conectada de alguma forma, ainda que desconhecida, com Nikolai Stavrogin, pois ele teria enviado grandes somas de dinheiro ao Capitão Lebiadkin, o bêbado e violento irmão de Maira. Resta claro no transcorrer da obra que a razão do pagamento do suborno era silenciar o Capitão Lebiadkin sobre o matrimônio secreto contraído entre Nikolai Stavrogin e a "louca" Maira, em Petesburgo, cinco anos antes. O matrimônio secreto contraído entre o revolucionário Stavrogin e a "louca" Lebiadkina é extremamente emblemático, pois personifica os simbolismos de pureza e de santidade da loucura na cultura russa, muito presente em Alexandr Pushkin e Fiódor Dostoiévski (ROSENSHIELD, 2003, p. 112-113).

A volta ao povoado, depois de anos no exterior, dos revolucionários Nikolai Stavrogin e Piotr Stiepánovitch Vierkhovénski, filho de Stiepan Trofímovitch Vierkhovénski, representa o começo da agitação política que permeia o romance. Diante da reinserção dos dois filhos da nobreza na vida social da província, logo começa a ficar clara a natureza dessa promíscua relação: a consolidação de uma célula terrorista, de cunho niilista, voltada ao fomento da turbulência política e da instabilidade revolucionária na região.

Nikolai Stavrogin e Piotr Stiepánovitch Vierkhovénski são os líderes dessa célula radical recém-instalada no pequeno povoado. Cada qual, contudo, persegue sua própria agenda. Piotr Stiepánovitch se destacará por suas ações e inclinações radicais, sem medo de praticar as mais cruéis violências políticas. Como referido acima, a 
história real do revolucionário Serguei Netcháiev - considerado um homem cruel por seu próprio companheiro na empreitada revolucionária, o veterano Mikhail Bakunin -, será o arquétipo do personagem Piotr Stiepánovitch.

A escalada da violência política atinge seu ponto culminante a partir da reunião de todos membros da célula revolucionária local, na qual tomam parte Nikolai Stavogrin, Piotr Vierkhovénski, Ivan Chátov, Alexei Kiríllov, o filósofo Shigaliev e outros jovens idealistas com distintas inclinações políticas. No decorrer da reunião, Piotr Vierkhovénski busca saber o real comprometimento de seus companheiros com a causa da revolução violenta. Indaga se informariam a polícia sobre os planos da organização em executar assassinatos políticos. Todos negam a possibilidade de trair o movimento sob pretextos morais individuais, abraçando a revolução a qualquer custo. $\mathrm{O}$ único que se insurge ao uso indiscriminado de violência é Chátov, que simplesmente abandona a reunião da célula subversiva, no que é seguido por Stavrogin e Kiríllov.

Nesse momento, instaura-se a nuvem de desconfiança para com Chátov, que começará a ser visto como potencial traidor do movimento. Diante da consternação que se instala entre os revolucionários, Piotr Vierkhovénski busca o apoio de Stavrogin. Começa a se acentuar a diferença de postura no que se refere à administração do empreendimento revolucionário. De modo dissimulado, Piotr Vierkhovénski tenta, de todas as formas, convencer Stavrogin da necessidade do emprego da violência extrema, a partir da clássica justificação dos meios pelos fins.

Com a intensificação das articulações revolucionárias, tornamse mais agudos os atos de perturbação política e social, como quando os operários da fábrica Spigulin realizam greves sob pretexto de implementação de melhores condições de trabalho e maiores salários. A escalada dos ânimos da sociedade deixa as autoridades da província em alerta, fazendo com que o governador Von Lemke passe a apresentar sinais de grave desgaste psicológico ao ter que administrar a crise instalada. 
Niilismo Jurídico e Ideologias Políticas Radicais: Uma Observação...

Nesse estado de espírito, o governador toma medidas autoritárias em resposta aos problemas como forma de restabelecer a paz social, ordenando a repressão às manifestações e a incursão policial na residência de Nikolai Stavrogin, identificando-o como artífice das ações subversivas. Durante a gestão da crise, Von Lemke irá efetivamente sucumbir à completa loucura, e os mais diversos atos de turbulência e agitação social se sucedem. Durante um incêndio criminoso na casa dos irmãos Lebiadkin, surge a notícia do assassinato da esposa de Nikolai Stavrogin, Maira Lebiadkina, e de seu irmão, o Capitão Lebiadkin. Trata-se de mais um ato dos revolucionários para acobertar o assassinato dos irmãos através da ação do fogo, a mando de Piotr Vierkhovénski e sob a complacência de Nikolai Stavrogin.

Em suma, o ódio que se dissemina sobre a província é avassalador. Influenciado pelos ideais de Piotr Vierkhovénski, o humilde engenheiro Alexei Kiríllov é convencido a se suicidar. Kiríllov, que vivia na mesma casa que Shátov, assume o fardo de se matar em nome da causa revolucionária e do bem maior da humanidade. Stavrogin o encoraja a perseguir o ateísmo extremo: pois, para os revolucionários, Deus não mais existe e, de agora em diante, apenas a vontade humana irá importar. A vontade pessoal de cada ser humano substitui, então, a representação divina. O convencimento do simples engenheiro Kiríllov a se sacrificar em nome de um grande bem está inserido nos planos de Piotr Vierkhovénski, que buscava desviar a atenção dos outros membros do grupo.

No momento crítico da trama, Piotr Vierkhovénski também ardilosamente convence seus companheiros revolucionários que Chátov irá denunciá-los e traí-los. Como Chátov renegou os princípios de violência revolucionária, voltando a professar a moral da fé ortodoxa, seus antigos amigos passam a vê-lo como ameaça e são traçados os planos para a sua execução. Liderados por Piotr Vierkhovénski, o grupo o conduz a um lugar ermo e, após ser rendido por seus companheiros, é executado por Vierkhovénski com um 
disparo de arma de fogo na cabeça. Na interpretação de Charles Taylor, Chátov simboliza a volta para a fé russa, os perigos do relativismo moral e a negação da tentativa de transformação radical do tecido social (TAYLOR, 2010, p. 817, 852 e 857).

O último capítulo da obra tornou-se célebre pela sua nãopublicação à época, em virtude da negativa do editor de Dostoiévski em publicar material de teor tão explícito e violento. Intitulado Com Tíkhon ou A confissão de Stavrogin, esse capítulo era considerado extremamente importante para Dostoiévski e geralmente vem publicado como apêndice nas edições contemporâneas d'Os demônios (DOSTOIÉVSKI, 2004, p. 655-687; DOSTOÏEVSKI, 1955, p. 707-751). Nesse momento de confissão, Stavogrin admite para o monge Tíkhon que teria estuprado e convencido uma menina de onze anos a cometer suicídio por enforcamento, tão somente porque estaria "entediado".

\section{O CONSTITUCIONALISMO LIBERAL RUSSO DIANTE DO NIILISMO E DAS IDEOLOGIAS POLÍTICAS RADICAIS}

Como se pode ver, o enredo d'Os demônios é permeado por questões essenciais da existência humana que se relacionam diretamente com as profundas transformações sociais ocorridas nos século XVIII e XIX. O atraso russo nesse processo de entrada na modernidade fica evidente na comparação com outros países da Europa. A perturbadora parte final do livro com seu conteúdo de abuso sexual de uma criança - e a posterior instigação ao suicídio finaliza a narrativa com tons definitivamente sombrios. 
A obra demonstra a desilusão de Dostoiévski com a natureza humana e sua postura cética diante dos projetos idealistas defendidos por amigos e colaboradores. A violência revolucionária do assassinato de Chátov simboliza apenas o exemplo mais óbvio do declínio da moral religiosa e da consagração de um processo de secularização disfuncional. O suicídio de Kiríllov em um ato de autodeificação, estreitamente vinculado ao seu engajamento com a filosofia niilista radical, representa outra mostra da crise de valores da época.

A crítica de Dostoiévski aos radicalismos daquele momento histórico tem uma origem mundana bastante clara: sua desavença com o autor de Pais e filhos, Ivan Turguêniev, pois o identificava como um dos artífices intelectuais das teorias revolucionárias niilistas. De um lado, encontram-se as rusgas e rivalidades de caráter pessoal entre os dois escritores; por outro, tem-se o eslavismo fervoroso de Dostoiévski contraposto ao ocidentalismo de Turguêniev. A concorrência brutal em termos de crítica e público entre Os demônios e Pais e filhos, assim como quanto ao conteúdo das teses de cada obra literária, será a tônica da rivalidade entre os dois escritores no decorrer da década de 1870 (FRANK, 2008, p. 517526).

A inspiração de Dostoiévski no Caso Netcháiev demonstra a sua preocupação em relação à situação política da Rússia. O grupo de Netchaiév havia tirado conclusões teóricas e cometido ações reais que, em Crime e castigo, Dostoiévski imaginara apenas como possibilidades extremas, de modo quase fantástico no pensamento delirante e paranóico de Raskólnikov (FRANK, 2008, p. 524). Tratava-se de uma geração que não utilizava mais os discursos retóricos, mas que passava a reivindicar as ações violentas como método de conquista do poder. Nikolai Stavrogin não é caraterizado como personagem marcado por fortes declarações e manifestos públicos, como seu tutor, Stiepan Trofímovitch, mas por ações e movimentos decididos. O mesmo ocorre com Piotr Vierkhovénski e suas inclinações pelo extremismo niilista (FRANK, 2008, p. 561). 
A recepção d'Os demônios no decorrer das décadas tem sido marcada por ocasionais acusações de difamação mal intencionada do movimento revolucionário russo. Em realidade, acredita-se que o escritor protagonizou o papel de adversário leal dos radicais, o que não faz dele um caluniador ou difamador malévolo da revolução. Obviamente, Dostoiévski reservou amplo grau de virulência em sua crítica à Turguêniev e a outros intelectuais alinhados à ideologia revolucionária, assim como retratou as organizações revolucionárias sob luz muito pouco favorável. Apesar disso, suas críticas ao que viria a se tornar a União Soviética, o stanilinismo e o totalitarismo russo certamente carregam o ar de profecia, e não de difamação gratuita (FRANK, 2008, p. 572-573).

O termo nïilismo se popularizou amplamente na Rússia com a recepção de Pais e filhos, de Turguêniev, que definiu seu protagonista, Bazárov, como um herói niilista. A publicação do romance coincide com o acirramento dos métodos de combate à autocracia russa. A redação e a publicação da obra do ocidentalista Turguêniev coincidem com a ocorrência de sucessivos incêndios criminosos de natureza política em São Petesburgo e Moscou (FIGUEIREDO, 2011, p. 7-15). Apesar de ter tecido comentários elogiosos à obra-prima de Turguêniev por seu valor estético, Dostoiévski identificava as crescentes ações de violência política da juventude como adesão perigosa ao niilismo como filosofia fundada no relativismo moral.

O termo Nïlismo deriva do latim, nihil, e começa a ser usado em profusão na modernidade a partir do século XVIII por F. H. Jacobi e J. P. Richter. Em Nietzsche, o emprego da palavra ganha refinamento, fazendo referência à superação dos valores tradicionais da sociedade pelo processo de secularização; ao mesmo tempo em que niilismo vem a representar a inexorável decadência da civilização ocidental e de seu conceito de homem (VATTIMO, 1985, p. 643-644). $\mathrm{Na}$ Genealogia da moral, Nietszche estabelece o caminho e os obstáculos que a civilização enfrenta em busca de um processo de secularização bem-acabado, pontuando habilmente as dificuldades 
na substituição da orientação divina, em franco declínio, por um nada moral; na retirada das balizas do que podemos definir com segurança como o bem e o mal (NIETZSCHE, 1987).

Para Löwith, desde muito cedo Nietzsche elabora uma sofisticada visão, em Wille zur Macht, sobre as origens da modernidade, em que os "próximos dois séculos" serão inexoravelmente marcados pelo advento do niilismo:

Com maestria psicológica, Nietzsche fez visível este niilismo europeu na sua origem histórica e em seus modos de aparição na ciência, na arte, na filosofia e na política. O resultado de seus quinze anos de reflexão foi a Vontade de potência, que também inclui a doutrina do eterno retorno.

O niilismo como tal pode significar duas coisas; ele pode não apenas ser o sintoma de uma decadência definitiva $e$ má vontade com a existência, mas pode também ser um primeiro sintoma de fortalecimento além de uma nova vontade de existir - um niilismo dos fracos ou dos fortes. Essa ambiguidade do niilismo como origem da modernidade é própria de Nietzsche (LÖWITH, 2014, p. 236).

A pregação da destruição da sociedade - e, mesmo, dos revolucionários como indivíduos, quando não alinhados com os ideais radicais -, pelos niilistas tinha como objetivo a derrubada de um regime efetivamente despótico, desigual e atrasado. Sob o pressuposto legítimo de resistência e de pressão por reformas, foram ignorados quaisquer limites ou balizas morais capazes de frear os influxos violentos. Violência essa que, como dito, estendia-se aos próprios companheiros de luta. Esse lado de aplicação prática das teorias radicais na Rússia figura como laboratório privilegiado para observar os paradoxos da modernidade.

A ideia de fundo de que a vida humana pode ser algo dispensável, com seu valor intrínseco relativizado em nome de algo maior, seduziu gerações de intelectuais e ativistas russos. Décadas mais tarde, esse modo de pensar e agir propiciou espaço no país para a criação e consolidação de um aparato estatal capaz de espionar, 
matar, torturar e escravizar indivíduos em nome da utopia social (BURLEIGH, 2010, p. 31-33).

Os detalhes da relação de companheirismo entre Necháeiv e Bakunin - e depois de ruptura, intriga e inimizade -, resgatado por Josef Frank, é ilustrativo dos contornos sinistros que o projeto revolucionário possuía já no século XIX:

Os "métodos" que Bakúnin critica agora com tanta severidade, e dos quais ele se dissocia com tanta impertinência, representam apenas a aplicação de doutrinas estabelecidas no conhecido Catecismo de um revolucionário, escrito ou por Netcháiev e Bakúnin em colaboração ou por um deles sozinho (ainda hoje se discute a questão). Não há dúvida que Bakunin tinha total conhecimento do mais sinistro dos manuais de estratégia revolucionária e havia aprovado seus preceitos. O que o horrorizava era apenas o fato de os métodos recomendados estarem sendo usados agora contra ele mesmo e contra seus amigos. É evidente que Dostoiévski não soube dessa carta; mas o espanto e a afronta que Bakúnin sentia por tornar-se a vítima de doutrinas que ele esposara no início lembram a reação de Stepan Trofímovitch às idéias e atividades do filho Piotr, que, no seu entender, está distorcendo e vulgarizando as idéias exaltadas que ele mesmo tivera na juventude. Assim, a carta de Bakúnin é valiosa não só porque constitui uma fonte de informação sobre Netcháiev, como também por ser uma prova da misteriosa precisão, mutatis mutandis, com que Dostoiévski captou a essência da relação histórica simbólica entre as gerações (FRANK, 2008, p. 578).

A busca pelo Homem Novo do niilismo coincidia com a tentativa de livrar a humanidade das amarras que a deixavam na escuridão, identificando na religião o principal adversário a ser combatido. Netcháiev concebia o "revolucionário" como um homem condenado a não possuir interesses pessoais, negócios, emoções, ligações, propriedades. O revolucionário sequer devia ter nome.

Mesmo não tendo acesso a tais fontes recentes da história russa, Dostoiévski conseguiu identificar o pano de fundo perverso que cercava a empreitada revolucionária. Nesse ponto, Os demônios é profético: na obra são eternizados os ditames de aniquilação total dos 
Niilismo Jurídico e Ideologias Políticas Radicais: Uma Observação...

inimigos ou potenciais inimigos da revolução. O tributo que Lenin e Stalin irão prestar a essas ideologias de destruição, exploração e descarte de outros seres humanos irá encontrar guarida na experiência russa. A ode à destruição total de quaisquer sistemas de valores se justificava, precisamente, em nome do "povo".

As numerosas referências do protagonista d'Os demônios, Stiepan Trofímovitch, aos ideólogos da reforma radical do tecido social - Fournier, Proudhon, Rousseau - são exemplificativas de um momento sensível na história da humanidade, o momento crítico de declínio da religião como um ícone moral. Diante do enfraquecimento da normatividade da moral-religiosa, a Rússia de Dostoiévski discutia qual o modelo que iria efetivamente substituir os preceitos religiosos na estrutura social. A proposta niilista, como visto, tinha seus próprios objetivos, consistentes em eliminar seus inimigos em troca de um objetivo redentor que justificava o emprego do radicalismo ideológico e do terrorismo revolucionário.

Em certo sentido, a ideologia niilista presente n'Os demônios implica conhecer os objetivos da política antecipadamente. É precisamente esse o componente principal do messianismo político que tomará conta do bolchevismo (que impregnará também o nazismo e o fascismo) e perdurará até os dias de hoje nos constantes recrudescimentos da política em diversos países. O indivíduo revolucionário radical que utiliza da indiscriminada violência política conhece - premonitoriamente - os objetivos da humanidade, sem necessidade de dialogar, compor, mediar ou debater. Com isso, decreta-se o fim da história: essa é a gênese do projeto totalitário.

No plano da teoria do direito, observa-se que n'Os demônios temos a antessala da subordinação do individual pelo coletivo. Seguindo-se de perto o itinerário histórico da Rússia do final do século XIX ao início do século XX, veremos que a submissão à volonté générale, cunhada por Rousseau, irá incensar o debate político-jurídico. Isso dará espaço para que, em um primeiro momento, as influências teóricas da revolução orbitem em torno da ditadura do proletariado de Marx e, conjuntamente, em torno da 
democracia totalitária de Rousseau. Isso porque o terrorismo revolucionário pregava a unidade e a unanimidade como projeto político-jurídico (TALMON, 1961, p. 38-49).

Para Todorov, Rousseau chega a esboçar os parâmetros para conceder autonomia ao indivíduo - e sonha com sua autossuficiência -, mas ao mesmo tempo investe na soberania do povo com a aclamação irrestrita da vontade das massas. Essa construção rousseauniana irá conduzir a um inevitável messianismo político com a prática da eleição por aclamação (totalizante por natureza). Com isso, observa-se o deslocamento do centro de cada indivíduo em direção às necessidades da coletividade; preocupa-se menos com o destino dos indivíduos e mais com os caminhos da sociedade. A sociedade tende a se tornar menos moral e mais política (TODOROV, 2012, p. 39-54).

A influência de Rousseau sobre Dostoiévski (e também Tolstói) já foi discutida em inúmeros trabalhos científicos. O famoso livro autobriográfico de Rousseau, suas Confissões, são trabalhadas minuciosamente por Dostoiévski através da confissão de pretensão redentora de Nikolai Stavrogin ao final do romance (COETZEE, 1992, p. 275-293). Nesse contexto, Stiepan Trofimovich seria o próprio arquétipo de Rousseau (MILLER, 2007, p. 86-104):

Quando os leitores comparam Stepan Trofímovitch a Rousseau, torna-se rapidamente evidente que ele é igualmente delirante, igualmente responsável por disseminar idéias atraentes que frequentemente têm consequências negativas, violentas e terríveis. No entanto, esse personagem que Dostoiévski retratou com ironia implacável, embora carinhosa, passa por uma autêntica experiência de conversão. (...)

Como Doistoiévski revela através de Stavroguin, a fórmula de Shigaliev é essencialmente uma projeção da noção rousseauniana da relação entre o eu e os outros nos campos social e político. A degeneração do sistema de Shigalev em ditadura se assemelha ao surgimento de uma tirania emocional a partir de uma cruzada em nome do cultivo da "singularidade" ilusória. É, no entanto, Stiepan Trofimovich que, no mundo do romance, foi o principal 
portador deste vírus das ideias de Rousseau (MILLER, 2007, p. 98, em tradução livre) 3 .

No que se refere a esse conceito de democracia totalitária, calcado em Rousseau, a indagação que surge está centrada no papel do direito como elemento capaz de frear a experiência totalitária e as ideologias radicais. Em parte, as propostas niilistas prosperaram na Rússia em razão da fraqueza de seu constitucionalismo como modelo de contenção dos influxos do radicalismo.

Com a ineficácia e fragilidade do direito como instrumento de pacificação social na Rússia, em parte decorrente de seu atraso histórico, a consolidação dos ideais fundados no terrorismo revolucionário irá se sobrepor às conquistas graduais do liberalismo típico do século XIX.

A história do direito russo foi marcada por um significativo atraso na modernização de suas instituicọes e pela obscuridade de seu ordenamento jurídico, especialmente quando comparada com a trajetória de outras nações europeias (FIORAVANTI, 1993, p. 153178; MATTEUCI, 1998, p. 259-284). Alguns historiadores, como Renè David, são partidários da tese segundo a qual a unidade do povo russo não tem como base o direito. Diferentemente da Itália ou do Brasil, lugares em que seria inimaginável uma sociedade sem direito e sem tribunais - por mais criticáveis e falíveis que sejam -, tal pensamento não causaria maior estranheza no âmbito da Rússia do século XIX. Em realidade, o principal componente normativo de coesão social do país era Cristianismo Ortodoxo Russo, e não o direito e suas instituições:

\footnotetext{
3 No original: "When readers compare Stepan Trofimovich to Rousseau, it quickly becomes evident that he is equally self-delusional, equally responsible for spreading attractive ideas that frequently have negative, violent, dire consequences. Nevertheless, this carachter whom Dostoievsky has portrayed with unrelenting, albeit affectionate, irony undergoes an authentic conversion experience. (...) As Doistoievsky reveals through Stavrogin, Shigalev's formula is essentially a projection of the Rousseauian notion of the relationship between the self and the others onto a social and political realm. The degeneration of Shigalev's system into a dictatorship parallels the rise of an emotional tyranny out of a crusade in the name of cultivating the elusive 'uniqueness'. It is Sitepan Trofimovich, however, who has, whitin the world of the novel, been the primary carrier of this virus of Rousseauin ideas".
} 
O mais grave não é o atraso, do ponto de vista técnico, do direito russo, nem o fato de ele só ter sido parcialmente codificado; o que importa sublinhar é que uma história diferente provocou no povo russo uma diferença de atitude perante o direito, contrastante com a dos outros povos europeus. Em toda a Europa continental, tal como na Inglaterra, o direito é considerado como um complemento natural da moral, e como uma das bases fundamentais da sociedade. Esta concepcãa do direito não se formou na Rússia. Até uma época recente, não houve juristas na Rússia: a primeira universidade russa, a de Moscou, só foi criada em 1755 e a universidade de Petersburgo, em 1802; uma literatura jurídica russa surge apenas na segunda metade do século XIX (DAVID, 1998, p. 151).

Essa história jurídica apresenta um cenário multifacetado sobre a relação entre direito e política: mostra a gênese da radicalização da política em um ambiente histórico marcado pela decadência e insuficiência do direito como elemento de coesão social. Nesse cenário, criou-se um lugar propício para substituição do norte moral religioso por alternativas marcadas pela radicalidade.

A história do direito russo é marcada por relevantes peculiaridades. Somente em 1832, durante o reinado de Alexandre I, é que o célebre ministro Speranski foi encarregado de levar a cabo o movimento de modernização do Direito russo, consistente no objetivo de codificação sistemática e eficiente, inspirada no modelo francês, que ao final não foi alcançado.

Ocorre que, com a eclosão da guerra contra Napoleão brilhantemente retratada em Guerra e paz por Tolstói -, e a consequente reação de ódio aos franceses, o projeto não obteve a recepcão positiva esperada, sobretudo pelo Conselho Imperial. O próprio Tolstói mostra esse cenário de comportamento ambivalente dos russos para com a cultura francesa diante da iminência da invasão napoleônica (TOLSTÓI, 2011). Soma-se a isso o fato de que o ministro Speranski foi acusado de ter apenas traduzido o Código Civil francês para o russo, o que lhe rendeu uma temporada de cerca de 
Niilismo Jurídico e Ideologias Políticas Radicais: Uma Observação...

dez anos de trabalhos forçados na Sibéria, entre 1812-1821, por ordem do Czar Nicolau I (LOSANO, 2007, p. 165-167).

Apesar da violência sofrida por Speranski, foi ele o responsável pela posterior "compilação" do direito russo, a pedido do Czar. O “Corpo das Leis do Império Russo” (Svod Zakonav Rossijskoj Imperii) era composto por quinze volumes e quarenta e dois mil artigos, e nas sucessivas ediç̃oes superaram a marca de cem mil artigos, dos quais mais da metade era dedicada a matérias de Direito Público (DAVID, 1998, p. 150-151). A profusão de fontes esparsas do direito russo dá mostras de quanto era obscura a estrutura legislativa do Império Russo, em que somente uma restrita parcela da elite tinha pleno domínio das leis imperiais. O "Corpo das Leis do Império Russo" buscava, ao menos, a unificação das fontes, revogando, consequentemente, as obscuras legislações ancestrais russas (LOSANO, 2007, p. 165-167).

Naturalmente, é importante não exagerar essa tradição russa de anti-legalismo. O objetivo dessa breve exposição foi mostrar algumas facetas do constitucionalismo russo e, assim, expor o tamanho dos desafios que foram enfrentados com firmeza por uma geração de constitucionalistas russos de corte liberal que confrontou juridicamente o ordenamento jurídico da autocracia russa. Trata-se de uma tentativa de dimensionar conceitualmente um fenômeno historicamente delimitado - a resistência ao direito, que o niilismo soube bem explorar -, com intuito de delinear como foram duros os processos de resistência à politização extrema e as tentativas de inserir um conteúdo valorativo no direito do Império Russo (WALICKI, 1992, p. 1-33).

Em síntese, esse era o tamanho do atraso da Rússia, um país sem um código nos moldes da França, e tampouco com uma constituição moderna. Os avanços foram substanciais na segunda metade do século XIX, mas ainda tímidos para as necessidades de um Império marcado pela servidão e pela desigualdade. Durante o reinado de Alexandre II, desenvolveu-se um consistente movimento liberal de reforma. Esse movimento, além de resultar na elaboração 
de um Código Penal (1855), foi marcado principalmente pela aboliçãa da servidão (1861) - que perdurou, de fato, até a Revolução Russa (1917) - e pela reforma da organização judiciária (1864), quando se separa a carreira da magistratura das carreiras administrativas e, finalmente, instituem-se tribunais profissionais (LOSANO, 2007, p. 157-172).

\section{5 "NIILISMO JURÍDICO RUSSO": EM BUSCA DE SIGNIFICADO}

A profecia de Dostoiévski das tragédias do século XX mostrou muito cedo os perigos da relativização moral e da justificação dos meios pelos fins. A conturbada e violenta história russa, desde a forma imperial, passando pelo duro período do regime soviético, atesta os percalços para se alcançar a estabilização política minimamente democrática. A literatura de testemunho do Arquipélago Gulag e dos Contos de Kolimá, por sua vez, explicita de modo inequívoco os resultados absurdos que a radicalização política pode gerar (CHALÁMOV, 2015).

Como visto acima, Os demônios abordou o desenvolvimento do niilismo enquanto filosofia radical, orientada por um relativismo moral, e sua utilização instrumental para fins revolucionários (CHERNYSHEVSKY, 1989). A filosofia niilista simbolizou o amadurecimento das experiências de agitação social de meados do século XIX (VENTURINI, 1960, p. 192-195, 316-330; GLEASON, 1968, p. $33,70-73$ e 102-103) ${ }^{4}$. No período de escritura d'Os

${ }^{4}$ Existe certa dificuldade para se definir o que poderia ser considerado o corpo teórico desse "niilismo filosófico", em grande parte pelo caráter polissêmico do termo e por ser esse conceito associado, majoritariamente, a um período histórico determinado, qual seja, o radicalismo político russo do século XIX. A discussão sobre o assunto é numerosa, e 
demônios, ainda havia alguma esperança de mudança nas relacọes sociais através da mediação do direito. A partir da abertura da circulação doutrinária com as nações ocidentais mais desenvolvidas, e também através de reformas institucionais, tornou-se possível recepcionar alguns dos elementos do constitucionalismo liberal europeu.

Contudo, ainda se enxergava um profundo fosso entre a moderna teoria do direito e a prática judiciária da Rússia czarista. Durante a vida de Dostoiévski, falecido em 1881, nunca seria promulgada uma Constituição, pois ela somente viria tardiamente na antessala da Revolução Russa, com a Constituição do Império Russo de 6 de maio de 1906. Em termos de direito comparado e teoria do direito, é interessante indagar sobre o alcance e o significado do que pode ser definido como nuilismo jurídico russo (nos moldes empregados por Jane Henderson ao resgatar um escrito de Alexandr Herzen), uma vez que a Rússia se notabiliza por sua relação extremamente conflituosa com o direito e por uma tradição arraigada de negativa do direito como elemento de resolução de conflitos (2011, p. 10-11).

O crescimento das ideologias niilistas na Rússia - ou de uma filosofia política niilista - e sua consequente instrumentalização prática em forma de atos de terror, deixou à mostra as debilidades do constitucionalismo russo, em grande medida incompleto no século XIX, com uma constituição outorgada somente em 1906, apenas poucos anos antes da Revolução Russa de 1917.

O fosso entre direito e realidade social no país deixou amplas margens para a sujeição do direito às finalidades políticas, pois os projetos de transformação radical tiveram êxito diante de instituições fracas e da não consolidação das conquistas constitucionais liberais típicas daquele período, como a organização de um sistema de separação de poderes mais equilibrado, a modernização da 
administração pública e o reconhecimento de alguns tipos de liberdade e garantias individuais.

Não ocorreu o estabelecimento de códigos, que possivelmente seriam capazes de tornar a legislação russa mais dinâmica. O mesmo se observa no que se refere às garantias e às liberdades individuais, que não foram implementadas a contento no sistema imperial e, muito menos, no totalitarismo soviético que se seguiu. Ao final do século XIX, o esgotamento e o desgaste do Império se tornou evidente, mesmo com a instituição da Monarquia Constitucional em 1906: a maior lacuna ainda era representada pela ausência de uma Constituição nos moldes das nações europeias ocidentais, que enfrentava a resistência do czar por se ver ameaçado diante do estabelecimento de um parlamento rival ao seu poder quase ilimitado.

\section{CONCLUSÃo}

Esse divórcio entre prática judiciária e realidade empírica colocava em evidência o abismo que dividia os costumes do povo e os ditames de um direito atrasado. A população camponesa libertada dos grilhões da servidão em 1861 não via o direito como um elemento norteador da vida social, e o mesmo acontecia em outros setores da sociedade. Esse fenômeno ora esboçado (que ainda merece ser trabalhado de modo mais aprofundado) pode ser denominado de "niilismo jurídico". Essa concepção negativa do direito - na qual o direito é descartado em favor de outros sistemas morais que enquadram a conduta humana - certamente não resta adstrita apenas à peculiar história russa, e serve como um quadro conceitual 
Niilismo Jurídico e Ideologias Políticas Radicais: Uma Observação...

capaz de ser aplicado em outros casos no direito constitucional comparado.

O percurso acidentado do constitucionalismo russo, exposto no decorrer do artigo de modo breve e fragmentado, proporciona uma visão valiosa sobre o papel do direito, dos juristas e das instituições no debate público. Atualmente, vive-se um novo ciclo agudo de crise de representação e das instituições democráticas liberais em todo o mundo. $\mathrm{E}$ o intuito do presente ensaio foi usar um caso emblemático da história política, através da literatura, precisamente para mostrar alguns dos desafios da pacificação social por meio do direito e de seus instrumentos. Num período de forte descrença popular com a forma democrática, com o liberalismo político e com o direito de um modo geral, espera-se que o trabalho sirva para amparar uma melhor compreensão dos fenômenos constitucionais. Em suma, a análise de determinados aspectos da trajetória de radicalização política e social que a Rússia viveu, pelo menos a partir de meados do século XIX até o começo do XX, pode funcionar como chave-de-leitura para o estudo de outros processos de constitucionalização, e como forma de refletir sobre os desafios que cercam tais percursos jurídico-políticos.

Data de Submissão: 17/03/2018

Data de Aprovação: 08/08/2018

Processo de Avaliação: double blind peer review

Editor Geral: Jailton Macena de Araújo

Editor de Área: José Ernesto Pimentel

Assistente de edição: Ilina Cordeiro de Macedo Pontes 
BAKHTIN, Mikhail. Problemas da poética de Dostoiévski.

Tradução de Paulo Bezerra. 5 ed. Rio de Janeiro: Forense

Universitária, 2015 · 341p

BURLEIGH, Michael. Blood \& rage. A cultural history of terrorism. Nova Iorque: Harper, 2010. 581p

CAMUS, Albert. Le mite de Sisyphe. Essai sur l'absurde. Paris: Gallimard, 2010. 170p

CAMUS, Albert. Les justes. Pièce en trois parties. Paris:

Gallimard, 2015. 15op

CAMUS, Albert. Les possédés. Pièce en trois parties adaptée du roman de Doistoïevski par Albert Camus. 12 ed. Paris: Gallimard, 1959. 301p

CHALÁMOV, Varlam. Contos de Kolimá. Tradução de Denise Sales e Elena Vasilevich. São Paulo: Editora 34, 2015. 304p

CHERNYSHEVSKY, Nikolai. What is to be done? Ithaca: Cornell University Press, 1989. 462p

COETZEE, J. M. Doubling the point: essays and interviews. Editado por David Attwell. Cambridge: Harvard University Press, 1992. 430p

DAVID, René; HAZARD, John N. El derecho sovietico. Tomo I. Buenos Aires: La Ley, 1964. 431p

DAVID, René. Os grandes sistemas do direito contemporâneo. São Paulo: Martins Fontes, 1998. 556p

DOISTOIEVSKI, Fiodor. Les démons. Bibliothèque de la Pléiade. Paris: Gallimard, 1955. 1345p

DOISTOIEVSKI, Fiodor. Os demônios. Tradução de Paulo Bezerra. São Paulo: Editora 34, 2004. 697p 
Niilismo Jurídico e Ideologias Políticas Radicais: Uma Observação...

DOISTOIEVSKI, Fiodor. Diario de un escritor. Crónicas, artículos, crítica y apuntes. Edição de Paul Viejo. Tradução de Elisa de Beaumont Alcade, Eugenia Bulátova e Liudmila Rabdanó. Madri: Páginas de Espuma, 2010. 1610p

FIGUEIREDO, Rubens. Bazárov e seus irmãos. In:

TURGUÊNIEV, Ivan. Pais e filhos. Tradução de Rubens Figueiredo. 2 ed. São Paulo: Cosac Naify, 2011. p. 7-15.

FIORAVANTI, Maurizio. Stato e costituzione. Materiali per una storia delle dottrine costituzionali. Torino: G. Giappichelli Editore, 1993. 238p

FRANK, Joseph. Dostoiévski: As Sementes da Revolta, 1821 a 1849. Tradução de Vera Pereira. São Paulo: Edusp, 2008a. 504p

FRANK, Joseph. Dostoiévski: Os anos milagrosos, 1865 a 1871. Tradução de Geraldo Gerson de Souza. São Paulo: Edusp, 2008b. 66op

GLEASON, Abbott. Young Russia. The genesis of Russian radicalism in the 1860s. Chicago: The University of Chicago Press, 1968. 437p

GONZÁLEZ, José Calvo. Derecho y literatura: Anatolií Fedorovich Koni (1844-1927). Sobre cultura jurídica de la literatura y cultura del derecho en la Rusia Imperial de Alejandro II a Nícolas II. In: GONZÁLEZ, J. C.. El escudo de perseo. La cultura literaria del derecho. Granada: Comares: 2012. p. 91-134.

HENDERSON, Jane. The Constitution of the Russian Federation: a contextual analysis. Oxford/Portland: Oxford University Press, 2011.

LOSANO, Mario G. Os grandes sistemas jurídicos. Tradução de Marcela Varejão. São Paulo: Martins Fontes, 2007. 677p

LÖWITH, Karl. De Hegel a Nietzsche. A ruptura revolucionária no pensamento do século XIX: Marx e 
Kierkegaard. Tradução de Flamarion Caldeira Ramos e Luiz

Fernando Barrére Martin. São Paulo: Editora da Unesp, 2014. 458p

MAGRIS, Cláudio. Utopía y desencanto. Historias, esperanzas e ilusiones de la modernidad. 3 ed. Barcelona: Anagrama, 2001. $364 \mathrm{p}$

MATTEUCCI, Nicola. Organización del poder y libertad. Historia del constitucionalismo moderno. Madrid: Trotta, 1998. 318p

MILLER, Robin Feuer. Dostoevsky's unfinished journey. New Haven: Yale University Press, 2007. 242p

NABOKOV, Vladimir. Lições de literatura russa. Tradução de Jorio Dauster. São Paulo: Três Estrelas, 2014. 400p

NIETZSCHE, Friedrich. Genealogia da moral. Tradução de Paulo Cesar Souza. São Paulo: Editora Brasiliense, 1987. 208p

OLIVO, Luis Carlos Cancellier (Org). Dostoiévski e a filosofia do direito. $O$ discurso jurídico dos irmãos Karamázov. Florianópolis: Editora da UFSC/Fundação Boiteux, 2012.

ROSENSHIELD, Gary. Pushkin and the genres of madness. The masterpieces of $\mathbf{1 8 3 3}$. Madison: The University of Wisconsin Press, 2003. 256p

ROSENSHIELD, Gary. Western law, russian justice. Dostoevsky, the jury trial, and the law. Madison: The University of Wisconsin Press, 2005. 309p

SOLJENÍTSIN, Alexandr. Arquipélago Gulag. 1918-1956. São Paulo: Círculo do Livro, 1975.

STEINER, George. Tolstói ou Dostoiévski. Um ensaio sobre o velho criticismo. Tradução de Isa Kopelman. São Paulo: Perspectiva, 2006. 276p 
Niilismo Jurídico e Ideologias Políticas Radicais: Uma Observação...

TALMON, Jacob Leib. The origins of totalitarian democracy.

New York: Frederick A. Praeger, 1961. 368p

TAYLOR, Charles. Uma era secular. Tradução de Nélio Schneider e Luzia Araújo. São Leopoldo: Editora UNISINOS, 2010. 930p

TODOROV, Tzvetan. Os inimigos íntimos da democracia. São Paulo: Companhia das Letras, 2012. 215p

TURGUÊNIEV, Ivan. Pais e filhos. Tradução de Rubens Figueiredo. 2 ed. São Paulo: Cosac Naify, 2011. 368p

VATTIMO, Gianni (Org). Nichilismo. In: Enciclopedia Garzanti di filosofia e epistemologia, logica formale, linguistica, psicologia, psicoanalisi, pedagogia, antropologia culturale, teologia, religioni, sociologia. Milano: Garzanti, 1985. p. 643644 .

VENTURINI, Franco. Roots of revolution. A history of the populist and socialist movements in ninetheenth-century Russia. Chicago: The University of Chicago Press, 1960. 85op

VILE, M. J. C. Constitutionalism and the separation of powers. 2. ed. Indianapolis: Liberty Fund, 1998. 455p

WALICKI, Andrezj. Legal philosophies of Russian liberalism. Notre Dame: University of Notre Dame Press, 1992. 477p

WORTMAN, Richard. S. The development of a Russian legal consciousness. Chicago: The University of Chicago Press, 1976. $345 \mathrm{p}$

ZAGREBELKY, Gustavo. Liberi servi. Il Grande Inquisitore e l'enigma del potere. Turim: Einaudi, 2015. 292p 


\title{
Legal Nihilism and Radical Political Ideologies: An Observation on the History of Russian Constitutionalism in Dostoevsky's "The Possessed"
}

\author{
Luis Rosenfield
}

\begin{abstract}
This article uses the novel The Possessed, by Fyodor Dostoevsky to address central issues of political philosophy and constitutional theory. In this study, literature serves as an axis of reflection that makes it possible to provide a consistent picture of the ideological crossroads of late nineteenth century, and its repercutions in history of ideas. In sumary, within the tradition of studies in law and literature and through essayistic methodology, it seeks to place the history of Russian constitutionalism in contrast to the rise of radical political ideologies. The investigation is organized (i) with the brief presentation of the life and work of Fyodor Dostoevsky; (ii) and in the deepening of the plot of The Possessed, focusing on the events of revolutionary violence and the political content of the novel; (iii) with the objective of constructing an analysis of Russian constitutionalism in the face of political radicalization, especially in its nihilistic form; (iv) in order to to outline a concept of "legal nihilism" through this analysis of the history of Russian law.
\end{abstract}

Keywords: Fyodor Dostoyevsky. Nihilism. Law and Literature. The Possessed. Constitutionalism. 